\title{
MIGRATION AND ECONOMIC DEVELOPMENT IN WESTERN BALKAN COUNTRIES: EVIDENCE FROM KOSOVO
}

\author{
Gezim Jusufi ${ }^{12}$ \& Mic Ukaj ${ }^{13}$
}

UDC / UDK: 314.7:338.1(497.115:497-15)

JEL classification / JEL klasifikacija: O15, J60

DOI: https://doi.org/10.22598/pi-be/2020.14.1.135

Scientific review / Pregledni znanstveni rad

Received / Primljeno: March 2, 2020 / 2. ožujka 2020.

Accepted for publishing / Prihvaćeno za tisak: May 15, 2020 / 15. svibnja 2020.

\section{Summary}

The aim of the paper is to identify the impact of the Western Balkans Diaspora on economic development of these countries, in particular Kosovo. Through qualitative methodological approaches the paper will review and analyze the definition and concept of migration, the reasons and factors of migration, migrations theories, the main destination for migrants, specifications of Kosovo population migration into years, the migration phases of the Kosovo population, the effects of migration or remittances on economic development of Kosovo, effective policies to strengthen the link between diaspora and development, remittance transfer channels and so on. From all the Western Balkan countries, Kosovo continues to be a significant trend for emigration because labour market is unable to absorb the high number of job seekers. Hence, the Kosovo institutions should promote investment and inform the Kosovo diaspora of facilities for doing business, and reforms that have been implemented in Kosovo. The limitations of this research may be the insufficient data and statistics on migration trends of the Western Balkan countries. Therefore, it was not possible to incorporate econometric analysis. The value of this paper, lies in dealing with Western Balkan migration problem, a problem that has been little addressed in the current academic literature.

Key words: Western Balkans, Migration, Development, Kosovo, Remittances.

\footnotetext{
12 Gezim Jusufi, Ph.D., Lecturer at High School of Economics in Gjilan, Kosovo, Email: gezimi.gjilan@gmail.com

${ }^{13}$ Mic Ukaj, Ph.D. Candidate at University of Prishtina, Lecturer at Fama College in Prishtina, Kosovo, E-mail: micukaj@hotmail.com
} 


\section{INTRODUCTION}

The official definition provided by international institutions identifies migration or an international migrant as any person who changes his or her country of usual residence for a minimum period of time. In particular, a "long-term migrant" is a person who does this "for a period of at least 1 year, so that the country of destination effectively becomes his or her new country of residence". A "short-term migrant" is a person who moves to a country other than that of his or her usual residence for a period of at least three months but less than one year, except in cases where the movement to that country is for purposes of recreation, holiday, visits to friends and relatives, business, medical treatment or religious pilgrimage (United Nations Educational, Scientific and Cultural Organization, 2017).

Three factors determine the rate of population growth of a country: Birth rate, death rate and rate of migration (emigration and immigration). The rate of migration is the most difficult to measure as so much depends on the reliability of the information obtained from different countries (Robinson, 1977). Migration as a process is not a phenomenon that has arisen in the present day, the roots of migration are very remote. People have migrated for certain political, social, economic, cultural, educational reasons. While there is broad consensus that the volume, diversity, geographical scope and overall complexity of migration have increased under the influence of broader globalization processes, these assumptions have not been subjected to systematic empirical assessment (Czaika and Haas, 2015).

Immigrants move more easily, send remittances to their countries, becoming a factor for many developing countries for their growth. Studies have shown that remittances can reduce the depth and severity of poverty in developing countries and that they are associated with increased household spending on health, education and SMEs. However, there's little evidence that they have much impact on overall economic growth in receiving countries (Pew Research Center, 2018). Castelli (2018) emphasizes that migration is always the result of a complex combination of macro, meso and micro factors, the former acting at the society level and the latter acting at the family or even individual level. The prevalence of a factor over the other is unpredictable. The origin of migration is not only globalization but also other factors: Political decisions such as the wars in Iraq and Syria, the North American Free Trade Agreement (Oil), the facilitation of migration policies.

A migrant can be defined as a person who changes their country of residence. More precisely a migrant can be someone whose country of birth is different to their country of residence or someone who changes their country of usual residence for a period of at least a year, so that the country of destination effectively becomes the country of usual residence (Sturge, 2019). The reasons of migration may also be 'push' or 'pull' factors. Push factors are those that force the individual to move voluntarily. Push factors may include pcverty/lcw wages, high unemployment, overpopulation, high taxes, corruption, discriminatory, etc. Pull factors are those factors in the destination country that attract the individual to leave their home. Those factors are high wages, demand for labor, strong economic growth, low cost of living, good health care and 
education systems, ect (Simpson, 2017). From the figure 1, it can be understood that migrants can be "pushed" out of their home countries due to poverty/low wages, high unemployment, poor health care or corruption. As result of these factors, migrants are often "pulled" into destinations that offer high wages, good health care and education systems, generous welfare benefits, law and order, or low cost of living.

Figure 1. Push and pull factors of migration

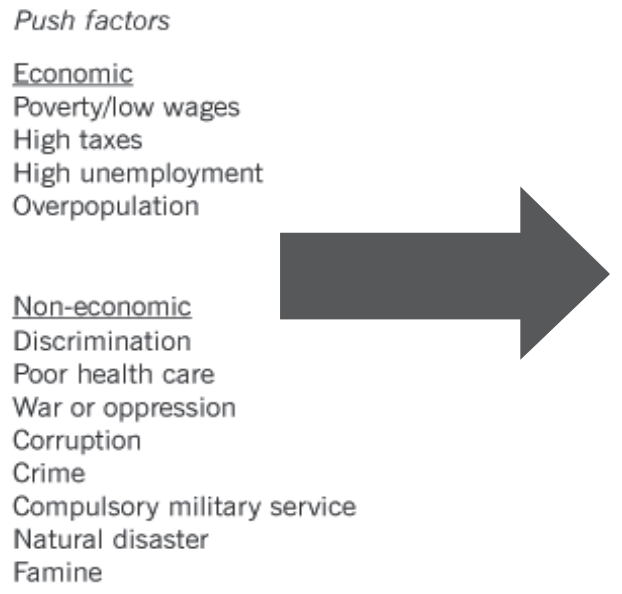

Pull factors

Economic

Demand for labor

High wages

Generous welfare benefits

Good healthcare and education systems

Strong economic growth

Technology

Low cost of living

Non-economic

Family and friends/networks

Rights and freedoms

Property rights

Law and order

Amenities

Source: Simpson, 2017

Natives in developed countries see immigration as a source of adverse economic effects, not as a stimulus for greater competitiveness. This is especially for immigration flows from developing countries. But when supported by appropriate policies, migration can contribute to economic growth in the country of origin and the host country. The main destination for migrants are developed countries for many attractive and motivating reasons. The US remains the country with the largest number of immigrants in the world. Destination countries also benefit greatly from migration, filling the labor market gap, reducing the cost of workers for many enterprises by exploiting migrants. The number of international migrations, including also refugees, increased in $258,000,000$ in 2017 , by $172,000,000$ as was in 2010 . Part of international immigrants in the world wide population increased by $3,4 \%$, as per $2,8 \%$, as it was in the same time period. $3 / 4$ of the increased migration in period of 2000-2017 was for the countries with the maximum incomes, where the part of international migrants, increased the number of population by $9,6 \%$ in $14 \%$ (Gashi, 2018). 


\section{LITERATURE REVIEW}

\subsection{Critical summary of migration}

There are numerous studies that analyze migration. Some of these studies present this phenomenon in a positive light while some others present it in a negative light. Migration solves social problems by alleviating unemployment, alleviating poverty, providing economic support, professional capacity building or quality enhancement obtained from developed countries. Immigration plays an important role in the transfer of capital investment and accelerates the exposure of traditional communities to liberal, rational, democratic ideas and modern knowledge. Getting higher salaries into host countries means that marginal production in these countries is higher than in the country of origin, this affects the relocation of people to these countries leading to an increase in global output worldwide (Bellaqa and Jusufi 2020).

The negative effects of migration include the cost to developing countries of losing labor and human capital to foreign labor markets, especially the "brain drain" (Taylor, 2006). According to Castles (2007) the social and economic costs of emigration can be high: The countries draw attention to the distress caused by long-term separation of families, the distortion of education systems re-shaped to meet the needs of destination countries, etc. Overall, emigration of labour whether skilled or less skilled can lead to serious loss of potential growth for the country of emigration. Telli (2014) examines the relationship between economic development in less-developed migrantsending countries and migrant flows from those countries to the developed countries. The study is motivated by the misconception that there is a linear relationship between the level of economic development and emigration from developing countries. Through panel data, the study finds that there is an inverse U-shaped relationship between economic development and emigration from developing countries to the developed countries, though this relationship is sensitive to aggregation of countries.

Some developed countries have a shortage of workers to fill positions in various sectors of their economies, or their working age population is steadily ageing without adequate replacement levels. These factors are the most important factors that influence migrations: demographic change, socioeconomic and political crises, and widening wage gaps between developed and developing countries (UNDP, 2009). Two types of economic differences encourage migration: Inequality between countries and inequality within a country. The world's nation-states have per capita incomes that range from less than $\$ 250$ per person per year to more than $\$ 50,000$, a difference that provides a significant incentive for people, especially young adults, to migrate for higher wages and more opportunities. Uneven geographic distribution in the growth of the world's labor force is another dimension of economic inequality between nationstates that adds to migration pressures. All labor force growth is projected to be in the lower-income countries: The work force in these countries is projected to increase by about 425 million between 2005 and 2015, while the labor force in higher-income countries is projected to remain stable (Martin and Zürcher, 2008). 


\subsection{Theories of migration}

Motives to migrate are complex. So, different migration theories should be viewed as complementary rather than contradictory (Andersson and Karpestam, 2018). In addition to the difficulties that all the social sciences experience when trying to explain human behaviour, migration theories face special ones: its subject matter is hard to define, difficult to measure, extremely multifaceted and multiform, and thus resistant to theory-building. While the reservoir of theories, and especially of conceptual frameworks, available nowadays represents a clear improvement over the situation a few decades ago, their contribution to our knowledge of migration is still limited (Arango, 2000).

The dominant theory in explaining causes of migration is the neoclassical theory with its underlying assumption that migration is stimulated primarily by rational economic considerations of relative benefits and costs, mostly financial but also psychological. The central argument of this theory concentrates on wages. Under the assumption of full employment, it predicts a linear relationship between wage differentials and migration flows. The neoclassical macro-level elaboration can be transferred to the micro-level model of individual choice and has been termed the human capital theory of migration. This theory enriches the neoclassical framework by incorporating the socio-demographic characteristics of the individual as an important determinant of migration at the micro-level (Kurekova, 2011).

The network theory does not look at the determinants which initiate migration but rather at what perpetuates migration in time and space. Haug (2008) studied the role of social networks in terms of location-specific social capital. It discusses relations between sociological and economic aspects of migration and outlines the influence of social capital on migration decision-making and chain migration processes. Social capital at the place of destination has positive impacts on emigration intentions and return migration, whereas social capital at the place of residence has negative impacts on return migration. Both neoclassical and the new economic theory conceptualize migration decisions as the outcome of rational economic calculations by individuals or families responding to objective market forces or constraints. Segmented labour market theory of migration takes a different perspective, where immigration responds to demand driven forces within structural imbalances of advanced economies. Capitalism gives rise to segmented labour markets where a primary market which generates high paying secure jobs coexists side by side with secondary market that is typically generating insecure, low paying jobs, and hazardous and unpleasant working conditions. Immigrants become desirable and are sought to fill jobs in the secondary market where residents shun away from certain occupations (Kubursi, 2005).

In Table 1, the main migration theories are presented. Initially all theories were classified into two groups based on the subject of analysis. The first group subject to analysis has the determinants of migration, while the second group has the perpetuation of migration. Then the theories are classified according to the level of analysis. Some theories have analyzed migration or its effects at the micro level, while others at the macro level. Meanwhile, the table also presents the variables that have been used in 
each theory to investigate the problem of migration. Finally, the main criticisms or shortcomings of these migration theories are presented.

Table 1. Overview of theories of migration

\begin{tabular}{|c|c|c|c|c|}
\hline Theory & $\begin{array}{l}\text { Subject of } \\
\text { analysis }\end{array}$ & $\begin{array}{l}\text { Level of } \\
\text { analysis }\end{array}$ & Pet variable(s) & Critique \\
\hline $\begin{array}{l}\text { Neoclassical } \\
\text { theory of } \\
\text { migration }\end{array}$ & \multirow[t]{4}{*}{$\begin{array}{l}\text { Determinants } \\
\text { of migration }\end{array}$} & $\begin{array}{l}\text { Macro } \\
\text { Micro }\end{array}$ & $\begin{array}{l}\text { Wage and } \\
\text { income } \\
\text { differentials } \\
\text { Probability of } \\
\text { employment }\end{array}$ & $\begin{array}{l}\text { Mechanically reduces } \\
\text { migration determinants - } \\
\text { exclusion of politics and } \\
\text { policies. } \\
\text { Assumes linearity - unable to } \\
\text { explain differential migration, } \\
\text { why people do not move, or } \\
\text { why migration ceases before } \\
\text { wage differentials equalize. } \\
\text { Ignores market imperfections. } \\
\text { Homogenization of migrants } \\
\text { and societies. } \\
\text { Static perspective. }\end{array}$ \\
\hline $\begin{array}{l}\text { Human } \\
\text { capital theory } \\
\text { of migration }\end{array}$ & & Micro & $\begin{array}{l}\text { Wages, } \\
\text { economic } \\
\text { benefits } \\
\text { affected by } \\
\text { individual } \\
\text { characteristics }\end{array}$ & $\begin{array}{l}\text { Overly optimistic view - } \\
\text { migration is not always a } \\
\text { voluntary process to } \\
\text { maximize gains. }\end{array}$ \\
\hline $\begin{array}{l}\text { New } \\
\text { economics } \\
\text { theory of } \\
\text { migration }\end{array}$ & & $\begin{array}{l}\text { Micro } \\
\text { Mezzo }\end{array}$ & $\begin{array}{l}\text { Wages and } \\
\text { income } \\
\text { distribution } \\
\text { (relative } \\
\text { deprivation) } \\
\text { Institutional } \\
\text { failures - } \\
\text { credit market, } \\
\text { labor market } \\
\text { deficiencies }\end{array}$ & $\begin{array}{l}\text { Critique of the neoclassical } \\
\text { theory rather than a theory in } \\
\text { its own right. } \\
\text { Sending side bias. } \\
\text { Limited applicability - } \\
\text { difficult to isolate the effect } \\
\text { of market imperfections and } \\
\text { risk in migration decisions } \\
\text { from other income and } \\
\text { employment variables. }\end{array}$ \\
\hline $\begin{array}{l}\text { World } \\
\text { system } \\
\text { theory }\end{array}$ & & $\begin{array}{l}\text { Macro: } \\
\text { global and } \\
\text { international } \\
\text { processes }\end{array}$ & $\begin{array}{l}\text { Structural } \\
\text { changes } \\
\text { induced by the } \\
\text { flow of capital }\end{array}$ & $\begin{array}{l}\text { Only applicable at the global } \\
\text { level. } \\
\text { Explanation formulated ex } \\
\text { ante, cannot be empirically } \\
\text { tested. }\end{array}$ \\
\hline
\end{tabular}




\begin{tabular}{|c|c|c|c|c|}
\hline $\begin{array}{l}\text { Dual labor } \\
\text { market } \\
\text { theory }\end{array}$ & & $\begin{array}{l}\text { Macro: } \\
\text { Nation state } \\
\text { Mezzo }\end{array}$ & $\begin{array}{l}\text { Labor demand } \\
\text { Bifurcation of } \\
\text { labor markets } \\
\text { FDI State } \\
\text { immigration } \\
\text { policies and } \\
\text { recruitment } \\
\text { efforts }\end{array}$ & $\begin{array}{l}\text { Receiving state bias - } \\
\text { excludes push factors, formal } \\
\text { recruitment. } \\
\text { Practices overemphasized. } \\
\text { Unable to account for } \\
\text { differential immigration rates } \\
\text { in different advanced } \\
\text { economies with similar } \\
\text { economic structures. } \\
\text { Distinction between primary } \\
\text { and secondary sector is } \\
\text { usually arbitrary which leads } \\
\text { to instability in empirical } \\
\text { estimates. }\end{array}$ \\
\hline $\begin{array}{l}\text { Network } \\
\text { theory }\end{array}$ & \multirow{3}{*}{$\begin{array}{l}\text { Perpetuation } \\
\text { of migration } \\
\text { and/or } \\
\text { directionality } \\
\text { of flows }\end{array}$} & Mezzo & $\begin{array}{l}\text { Networks, } \\
\text { diaspora }\end{array}$ & $\begin{array}{l}\text { Conceptual framework rather } \\
\text { than a theory. } \\
\text { Networks can be } \\
\text { exclusionary and undermine } \\
\text { (not facilitate) migration. }\end{array}$ \\
\hline $\begin{array}{l}\text { System } \\
\text { theory }\end{array}$ & & Macro & $\begin{array}{l}\text { Developmental } \\
\text { space }\end{array}$ & $\begin{array}{l}\text { Purely descriptive. } \\
\text { Unable to account for decline } \\
\text { of migration systems } \\
\text { overtime. }\end{array}$ \\
\hline $\begin{array}{l}\text { Transnational } \\
\text { migration }\end{array}$ & & $\begin{array}{l}\text { Transnational } \\
\text { level }\end{array}$ & $\begin{array}{l}\text { Transnational } \\
\text { social spaces }\end{array}$ & $\begin{array}{l}\text { Novelty of the concepts has } \\
\text { been questioned. } \\
\text { Research within this } \\
\text { paradigm usually selects on } \\
\text { dependent variable. }\end{array}$ \\
\hline
\end{tabular}

Source: Kurekova, 2011

System Theory emphasizes migration from peripheral developing countries to core capitalist ones. Migrants flow from the periphery to the core while capital, machinery, and goods flow from the core to the periphery. This often creates a loop: capital and machinery, for instance, may increase agricultural productivity, forcing people to move internally to cities and cause high youth unemployment in urban areas. These youths may end up migrating to more advanced economies (European Commission, 2018).

The political economy model explicitly focuses on the political mechanisms generating transnational population flows. This approach views receiver- country or region (for example, the European Union as a supranational body) immigration policies, including regulations of entry, duration of sojourn, permission to work, the treatment of unauthorized immigrants, and of citizenship as directly shaping the volume and directions of international migration. Advocates of the political economy approach forcefully argue for the recognition of the importance of the realm of political decisions as a causal force in shaping international population flows (Morawska, 2007). 


\section{MIGRATION IN THE WESTERN BALKANS}

The Western Balkans is a geopolitical term coined by the governing bodies of the EU in the early 2000s and referring to those countries in Southeastern Europe that were not EU members or candidates at the time but could aspire to join the bloc. The Western Balkan consisted of six countries: Albania, Bosnia and Herzegovina, Kosovo, North Macedonia, Montenegro and Serbia (Dabrowski and Myachenkova, 2018). This region has a lot of economic and human potential, and yet is not often considered by companies and entrepreneurs from other parts of the world (Jusufi and Lubeniqi, 2019). According to Baković (2010) companies from transition economies need to be aware that internal capabilities such as innovation-oriented culture, entrepreneurship and market orientation are among important drivers of wealth creation and growth.

Currently, about 4.5 million people from the Western Balkans are living outside their country of origin and still maintain close ties to these countries. Through knowledge and technology transfer, investments and other financial contributions, the mobilization of networks and contacts, these migrants are able to promote innovation and development processes in their countries of origin (GIZ and CIM, 2014). Table 2 shows the population trends, migration, unemployment and poverty rates of the Western Balkan countries. As can be seen from this table, all countries in this region are experiencing a demographic decline due to higher emigration and lower birth rates. These statistics show that demographic movements in these countries do not have positive growth dynamics.

Table 2. Migration in Western Balkan countries

\begin{tabular}{|l|l|l|l|l|l|}
\hline Country & $\begin{array}{l}\text { Population } \\
\text { growth } \\
(\%)\end{array}$ & $\begin{array}{l}\text { Net } \\
\text { migration } \\
\text { rate }\end{array}$ & $\begin{array}{l}\text { Median } \\
\text { age }\end{array}$ & $\begin{array}{l}\text { Unemployment } \\
(\%)\end{array}$ & $\begin{array}{l}\text { Population } \\
\text { below poverty } \\
\text { line (\%) }\end{array}$ \\
\hline Albania & 0.31 & -3.3 & 32.9 & 14 & 14.3 \\
\hline B\&H & -0.16 & -0.4 & 42.1 & 20.5 & 17.2 \\
\hline Kosovo & - & - & 29.1 & 34.8 & 30 \\
\hline $\begin{array}{l}\text { North } \\
\text { Macedonia }\end{array}$ & 0.17 & -0.5 & 37.9 & 23.4 & 21.5 \\
\hline Montenegro & -0.2 & - & 40.7 & 17.1 & 8.6 \\
\hline Serbia & -0.46 & 0 & 42.6 & 16 & 8.9 \\
\hline
\end{tabular}

Source: Šelo Šabić, 2018

Also it should be emphasized that few parts of Europe are more marked by emigration than the Western Balkans. The population of this region has grown smaller and older over the last few decades. But even though many people have left, data about them remain sparse. The region is yet to fully grasp just how beneficial its diaspora could be for its future and even if it wanted to, it would quickly come up against a lack of hard evidence on which to base new policy decisions. The current expected average Western Balkans GDP growth rate of around 3\% is insufficient to accelerate the process 
of catching up with other European countries. GDP is projected to have risen to $3.2 \%$ in 2018 and to rise by $3.5 \%$ in 2019 , but if this growth rate continues, it would take six decades for the average per capita Western Balkan income to converge with the EU average (Vračić, 2019). From Table 3 it can be understood that personal remittances play an important economic and social role in all Western Balkan countries, except North Macedonia. In Bosnia \& Herzegovina and Kosovo their share of GDP exceeds $10 \%$ while in Serbia, Albania and Montenegro they amount less than $10 \%$. 


\begin{tabular}{|c|c|c|c|c|c|c|}
\hline 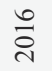 & $\stackrel{\infty}{\infty}$ & @) & $\begin{array}{l}\stackrel{\infty}{ \pm} \\
\dot{ \pm}\end{array}$ & $\vec{a}$ & $\hat{i}$ & $\underset{\infty}{+}$ \\
\hline$\stackrel{n}{\stackrel{n}{\sim}}$ & $\tilde{a}$ & $\Xi$ & $\vec{n}$ & $\stackrel{t}{\sigma}$ & $\vec{r}$ & $\vec{a}$ \\
\hline$\stackrel{\Delta}{\stackrel{\sim}{2}}$ & $\underset{\infty}{\infty}$ & $\stackrel{+}{\Xi}$ & $\dot{I}$ & $\stackrel{t}{\circ}$ & $\ddot{n}$ & $\underset{\infty}{+}$ \\
\hline$\stackrel{m}{\stackrel{n}{\vec{n}}}$ & $\begin{array}{l}0 \\
\infty \\
\infty\end{array}$ & $\stackrel{\check{0}}{\circ}$ & \pm & $n$ & $n$ & $\begin{array}{l}\infty \\
\infty \\
\infty\end{array}$ \\
\hline$\stackrel{\overbrace{}}{\stackrel{\sim}{~}}$ & $\stackrel{n}{=}$ & $\hat{\stackrel{\theta}{\theta}}$ & $\begin{array}{l}\stackrel{\circ}{ \pm} \\
\dot{\Xi}\end{array}$ & $\hat{\sigma}$ & $\nabla$ & $\hat{\infty}$ \\
\hline$\overline{\vec{\sim}}$ & $\simeq$ & $\ddot{n}$ & $\stackrel{\partial}{ \pm}$ & $\begin{array}{l}\infty \\
\infty \\
\infty\end{array}$ & $\vec{r}$ & $\stackrel{n}{\infty}$ \\
\hline$\stackrel{\circ}{\circ}$ & $\stackrel{\oplus}{\stackrel{\oplus}{~}}$ & $\begin{array}{l}\circ \\
\stackrel{\square}{\circ}\end{array}$ & $\stackrel{?}{=}$ & $\vec{\infty}$ & $F$ & $\stackrel{\leftrightarrow}{\subseteq}$ \\
\hline छे & $\stackrel{m}{+}$ & $\vec{i}$ & $\hat{\infty}_{\infty}$ & $?$ & $\exists$ & $\hat{o}$ \\
\hline$\stackrel{\infty}{\stackrel{8}{\circ}}$ & $\stackrel{n}{ \pm}$ & $\stackrel{\mathscr{I}}{ \pm}$ & $\stackrel{m}{\infty}$ & : & $\bar{F}$ & $\stackrel{丶}{\curvearrowright}$ \\
\hline ڤ్) & $\overrightarrow{\ddot{m}}$ & $=$ & 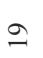 & $\stackrel{\vec{r}}{\mathrm{n}}$ & $\bar{F}$ & $a^{2}$ \\
\hline \& & $\overrightarrow{\mathrm{n}}$ & $\hat{\sigma}$ & $\stackrel{\infty}{\infty}$ & . & $\dot{m}$ & , \\
\hline ڤి & $\begin{array}{l}\infty \\
\ddot{n}\end{array}$ & $\stackrel{\sim}{\mathscr{\infty}}$ & $\begin{array}{l}\infty \\
\stackrel{\infty}{\Theta}\end{array}$ & , & $\stackrel{\circ}{r}$ & , \\
\hline ఫ্ণ & $\hat{n}$ & ֶֶ. & $\overparen{I}$ & . & $\dot{m}$ & . \\
\hline ڤ్రి & $\begin{array}{l}n \\
n\end{array}$ & $\begin{array}{l}\infty \\
\stackrel{\sim}{\sim}\end{array}$ & , & , & $\stackrel{n}{m}$ & , \\
\hline §ิ & ?ֶ. & $\begin{array}{l}n \\
i \\
i\end{array}$ & ' & , & $\begin{array}{l}\mathbf{i} \\
i\end{array}$ & , \\
\hline$\overline{\mathrm{d}}$ & $\stackrel{\cong}{I}$ & $\overrightarrow{\mathrm{d}}$ & ' & , & $\sim$ & , \\
\hline ষ্ণ & $\stackrel{t}{\circ}$ & $\hat{\stackrel{\phi}{\sim}}$ & ' & , & $\bar{i}$ & , \\
\hline $\begin{array}{l}\text { 音 } \\
\text { ठ }\end{array}$ & 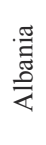 & 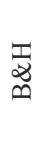 & 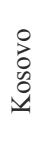 & 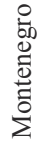 & 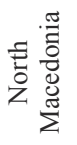 & 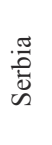 \\
\hline
\end{tabular}


This region has had a bad and difficult past. For the past two decades most countries in this region have been occupied with addressing the consequences of the 1991-1995 conflicts, including the large-scale intraregional displacement. Migration has been defined primarily by outflows of Western Balkan nationals. Long-simmering political, ideological, economic and ethnic tensions among the nations of the Socialist Federal Republic of Yugoslavia erupted when Slovenia and Croatia declared independence in 1991 and further intensified with the secession of Bosnia and Herzegovina in 1992.

After the dissolution of Yugoslavia, 3.5 million individuals left the region. Hence, the emigration rate has been at $19.4 \%$, and ranging from $9.1 \%$ in Serbia to $38.5 \%$ in Albania. As a consequence, remittance flows have been sizable: The entire region received 8.6 billion USD in 2015, ranging from 3.1\% of GDP in North Macedonia to $16.7 \%$ in Kosovo. These figures still considerably exceed the inflows from foreign direct investment and official development assistance, 5 and 2.4 billion USD, respectively, hence reflecting the massive dependence of region's economies on the money the diaspora sends back (Petreski et al, 2017).

Economic stagnation and unemployment have triggered waves of labour migration. Many labour migrants could rely on the support provided by large diaspora communities established abroad over decades of outmigration and refugee movements. The presence of well-established diasporas, along with other factors, such as availability of job opportunities and comparably higher wages, have made Western Europe (mainly Germany, Austria, France, Switzerland) an attractive destination for labour migrants from the Western Balkans. Greece and Italy also emerged as important countries of destination, especially for seasonal labour migration from Albania (Zitnanova, 2014).

According to Mustafa-Topxhiu and Xhelili-Krasniqi (2017) diaspora has a positive effect on economic development of the region. Their study utilizes a strongly balanced panel data over the 2005-2015 period for the six Western Balkan countries using the ordinary Least Squares Method, the Pooled Regression Model to evaluate the parameters. According to the results, remittances have a positive impact on economic growth and can foster economic growth in the Western Balkan. Also, they find a statistically significant positive relationship between economic growth and other variables such as exports, capital formation and labor.

It is characteristic that individuals from the Western Balkan are closer to the individuals from developed countries (in terms of value) than the social systems in this region are to those in developed countries. This disparity is another generator of the increased migration flow from this region to developed countries. The mentioned reason, combined with the state of the rule of law, adherence to laws, corruption perception, extent of discrimination based on sexual orientation, freedom of speech, as well as the perception of the outlook of this region create a broad range of push factors which become more intense in certain time periods (WFD et al., 2019). In short, the problem of migration is widely expressed in this region.

In Western Balkans, the problem with migration is that although it raises aggregate incomes, it does tend to reduce, other things being equal, the wages of some of the receiving country's workers. One can take for granted that migration raises the 
incomes of the migrants otherwise they would not choose to migrate. Migration also raises the return to capital, hence profits, in the receiving country. But the increase in the receiving country's labour pool might reduce the wages of incumbent workers in certain industries. The net result is an increase in the receiving country's aggregate income and an expansion in its tax base. From this overall gain, governments could compensate the domestic workers who see their incomes fall and still leave everybody better off (Mungiu-Pippidi, 2005).

Krasniqi and Williams (2019) demonstrate that the entrepreneurial intentions of returning diaspora are affected by their level of trust and perceptions of risk in institutions at home. Through a survey of diaspora returning to Kosovo, their research finds that business experience has a negative relationship on probability to return, but it has a positive relationship on entrepreneurial intentions. However, those with professional and qualified jobs are more likely to have intentions to return, but less likely to have entrepreneurial intentions.

\section{KOSOVO INTERNATIONAL MIGRATION FLOWS}

Population in Kosovo in 2018 is estimated to be 1,795,666 residents. Albanians make up $88 \%$, Serbs $7 \%$ and other communities $5 \%$ of the total population. More than $35 \%$ of the population is young (KAS, 2019). Kosovo is one of Europe's poorest countries with about $40 \%$ of the population living below the poverty line, and has one of the highest unemployment rates in Southeast Europe. In Kosovo, the unemployment rate measures the number of people actively looking for a job as a percentage of the labour force. Unemployment rate in Kosovo decreased to $25.30 \%$ in the second quarter of 2019 from $26.90 \%$ in the first quarter of 2019. Unemployment rate averaged $35.39 \%$ from 2001 until 2019 , reaching an all-time high of $57 \%$ in the fourth quarter of 2001 and a record low of $25.30 \%$ in the second quarter of 2019 (Trading Economics, 2019). Given the poor prospects of employment, individually emigration can be a strategy to escape unemployment and contribute to family income. 
Figure 2. Population with citizenship of Kosovo

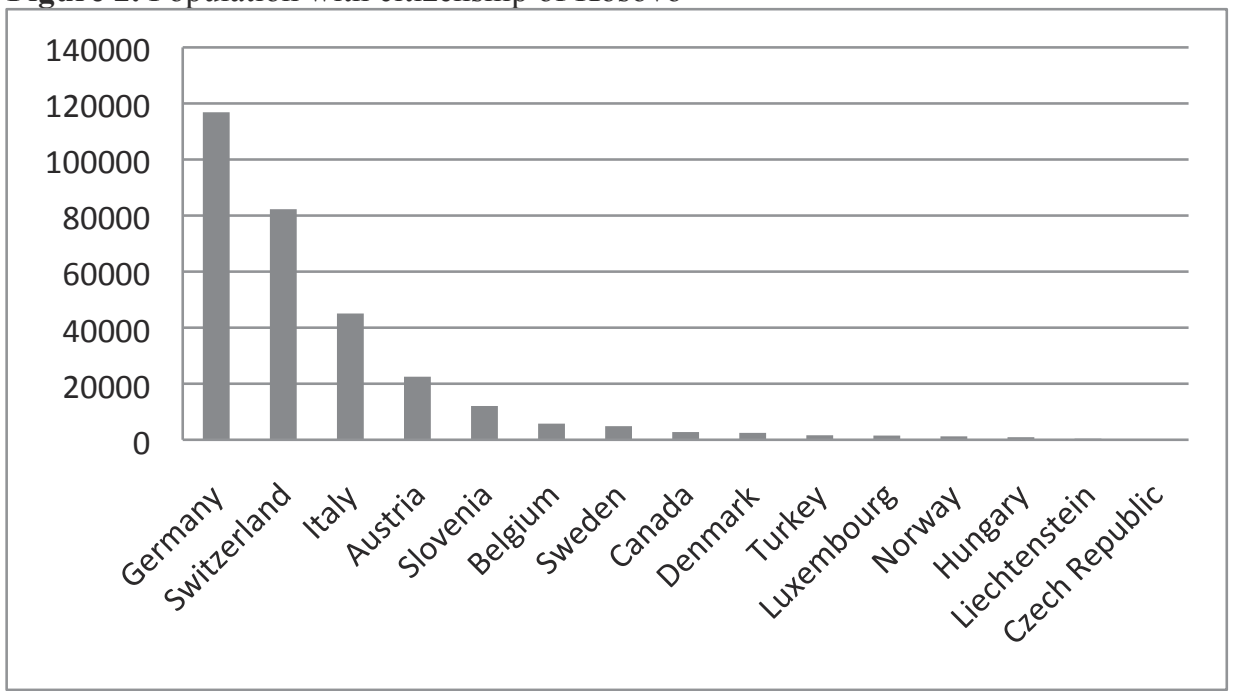

Source: Möllers et al, 2017

Over $35 \%$ of total Kosovo's population had emigrated to Germany, followed by Switzerland with around $23 \%$, and Italy over $7 \%$. Other countries, including Canada and Australia, comprised of over $10 \%$ of the Kosovan migrant population (KAS, 2014). According to Kotorri (2010) the probability of emigration from households in Kosovo is found to be influenced by relative wealth, type of area and regional unemployment rates. Kosovo has historically faced several waves of migration, whether for economic, political or social reasons. Table 4 shows the percentage of immigrants from Kosovo for each stage or phase of emigration.

Table 4. Distribution of Kosovar emigrants by stages of emigration

\begin{tabular}{|l|l|}
\hline The wave of emigration & $\%$ of immigrants \\
\hline Phase I & $7.1 \%$ \\
\hline Phase II & $32.9 \%$ \\
\hline Phase III & $7.9 \%$ \\
\hline Phase IV & $52.1 \%$ \\
\hline
\end{tabular}

Source: Kosovo Agency of Statistics, 2013

The periods of migration can be divided into four stages;

Phase I (1960-1988): Emigration was initially as seasonal workers. The first period deals with the temporary migration of workers to Switzerland and Germany. These migrant workers have been from rural areas of Kosovo with a low education and they have had special employment contracts. In 1981 there were about 27,000 emigrants from Kosovo, and between 1981 and 1987 another 50,000 people left. Heavy waves of 
migration continued after 1989 after the breakup of Yugoslavia for economic reasons (Hoti, 2015).

Phase II (1989-1997): The 1990's wave dominated by better-educated, skilled and better off Kosovar Albanians from urban areas, who emigrated primarily to avoid military service in the Yugoslav army during the wars in Yugoslavia, was primarily concerned with their own education and far less on remitting (Gashi and Haxhikadrija, 2012). Remittances have made some very distinct contributions during this phase. It was the diaspora that paid for the parallel education and health structures during the 1990 s, responding to a call from the 'government in exile' when a large number of intellectuals were dismissed from their jobs and education in Albanian was banned. The diaspora is said to have sponsored the Kosovo Liberation Army and made a very important contribution to the reconstruction of Kosovo after the conflict (Vathi and Black, 2007).

Phase III (1998-1999): The next phase occurred in 1998 during the outbreak of the war in Kosovo, which led to a phase of mass emigration to Europe and other countries. Between March and June 1999, an estimated 850,000 refugees fled into neighbouring Albania, North Macedonia and Montenegro, threatening wider regional instability. Some 200,000 people were internally displaced or homeless inside Kosovo itself (Gollopeni, 2016).

Phase IV (2000-2015): At this stage migrants moved westward for family reunification. Also they migrated for economic reasons. In recent years, economic growth has brought about $4 \%$, and this growth has been driven by public and private investments, which do not bring about any improvement in labor market conditions (European Stability Initiative, 2015).

\section{THE IMPACT OF MIGRATION ON ECONOMIC DEVELOPMENT OF KOSOVO}

Migration and remittances have been of considerable importance to the economy and households of Kosovo since the late 1960s and continue to be so even today. Its importance is reflected both at micro (household) as well as macro level (GLPS, 2017). Despite the negative effects it has on population decline, migration contributes to stabilizing employment, in particular reducing the unemployment rate. Each year migration absorbs approximately one in two young individuals in the labor market. Therefore, migration plays an important role in reducing the unemployment rate. Immigrant households participate less in the labor market than households without them. Returning migrants will continue to bring to Kosovo experience and knowledge obtained abroad, as evidenced by their improved education.

During their stay abroad, migrants continue to have economic, cultural, and political relationships with their home country. The main economic activities are remitting money, consuming home country products, investing in the home country (mostly in housing construction), and engaging in philanthropy there. The economic strength of the emigrant determines both the size of these activities and the policies that 
the government creates to facilitate transactions and the investment climate. The return of migrants depends on economic, political, and social circumstances in the home country. When migrants decide to return, they often bring savings, how they use these savings depends on a number of policies, such as ease of doing business and availability of information about investment opportunities. Moreover, migrants can bring new skills and knowledge that can build up the human capital of the home country.

Kosovo needs to establish an institutional framework to realize its vision of how migration will contribute to Kosovo's development. The choice of institutional alternative will depend on the domestic context, including funding constraints, but in any case institutional capacity needs to be considerably reinforced. Remittances are the largest source of Kosovo's external funding, measures to facilitate their transfer and reduce costs should be a priority. The authorities should therefore direct their attention to promoting competition for transfers and enhancing the financial literacy of remittance senders and recipients.

Migration has reached an important dimension everywhere in the world. Immigrant remittances to developing countries reached large sums of dollars. Therefore, developing countries should use these financial flows for economic and social development. From international experience Kosovan authorities can learn more about how migration and development intersect and how policy choices can influence these linkages to the benefit of economic development. Increasing GDP for many developing countries can lead to an increase in immigration rather than a decrease. Increasing income can create a good base for financing the migration of many social strata and one of them would be those with high human capital that could be considered brain drain. The type of migration that Kosovo has experienced cannot be considered a brain drain because $92 \%$ of migrants have no more than secondary education, only $5 \%$ had a bachelor's degree when they left Kosovo (World Bank, 2011).

\section{THE IMPACT OF REMITTANCES ON KOSOVO ECONOMIC DEVELOPMENT}

The Kosovar diaspora is spread all over the world. Kosovo's Remittances data was reported at 220.709 Euro in June 2019. This records an increase from the previous number of 184.659 Euro for March 2019. The data reached an all-time high of 220.709 Euro in June 2019 and a record low of 108.742 Euro in March 2012 (CEIC, 2019). Money sent from the Diaspora represents the most important financial source for the people of Kosovo. For many transition and developing countries, external funding is very important. Especially for Kosovo which should identify its comparative advantages, increase the competition capabilities of local firms, improve the business environment and use EU financial assistance more effectively to compete regionally and in the EU market (Qorraj and Jusufi, 2018).

Kosovo is considered to be one of the largest in the diaspora in proportion to the total number of citizens within the country. Countries leading the remittances also include economically developed countries where Germany leads with $34 \%$, Switzerland 
with 23\% and Italy with 7\% (Germin \& DANIDA and SDC, 2018). Based on statistics on the Kosovar population living in the diaspora, it turns out that around 700,000800,000 people who were born in Kosovo currently live abroad. Remittances as a source of financing for Kosovo continue to be above the level of FDI due to the large Kosovo Diaspora and the unfavorable climate for foreign investment which was not satisfactory at this time. Various studies suggest that migration results in a significant increase in global welfare; developed countries can increase global welfare by opening the door for more immigrants (Bellaqa and Bajrami, 2019). Table 5 presents remittance transfer channels, by gender of emigrant. As can be seen, remittance transfers in Kosovo are mostly made through friends or emigrants. This is the preferred channel for Kosovar emigrants to transfer remittances.

Table 5. Remittance transfer channels, by gender of emigrant

\begin{tabular}{|l|l|l|}
\hline Transfer channel & Women & Men \\
\hline Bank transfer & $29.0 \%$ & $40.5 \%$ \\
\hline Credit/debit card & - & $1.2 \%$ \\
\hline Money transfer agency & $13.9 \%$ & $16.9 \%$ \\
\hline Post office & - & $0.9 \%$ \\
\hline In-person (by emigrant or friend) & $57.2 \%$ & $40.5 \%$ \\
\hline
\end{tabular}

Source: UNDP, 2012

Remittances in Kosovo have a very high share in the economic development of GDP. Remittances account for a total of $20.64 \%$ of GDP. After Kosovo is ranked Bosnia and Herzegovina with about $11 \%$, and Albania with $10.8 \%$, while Greece's lowest share with $0.35 \%$. Particular importance is given to Kosovo, which has as a result that the percentage of remittance participation has a high positive correlation with the percentage of participation in Serbia, whereas the high negative correlaction with Montenegro's. In general, in most of the Balkan countries, remittances and their trend are projected to decrease, and according to the trend application, we can see that remittances in Kosovo tend to increase (Jashari and Geci, 2018). From Table 6 it can be understood that the share of remittances in Kosovo's GDP during the eight-year period 2008-2016 was about $10-15 \%$.

Table 6. Remittance to GDP ratio (in million Euros)

\begin{tabular}{|l|l|l|l|}
\hline Year & Remittances & GDP & \% that remittances occupy on GDP \\
\hline 2008 & 609 & 3,883 & $15.68 \%$ \\
\hline 2009 & 586 & 4,070 & $14.40 \%$ \\
\hline 2010 & 584 & 4,402 & $13.27 \%$ \\
\hline 2011 & 493 & 4,815 & $10.24 \%$ \\
\hline 2012 & 516 & 5,059 & $10.20 \%$ \\
\hline 2013 & 573 & 5,327 & $10.76 \%$ \\
\hline 2014 & 622 & 5,567 & $11.17 \%$ \\
\hline 2015 & 665 & 5,807 & $11.45 \%$ \\
\hline 2016 & 691 & 6,070 & $11.38 \%$ \\
\hline
\end{tabular}

Source: Prekazi, 2018 
Investments from the Diaspora are very welcome for the economy of Kosovo, they should be increased due to their great role in improving the economic situation in the country. Approximately $10 \%$ of total investment in the privatization process is a contribution of diaspora to privatization. The diaspora's entrepreneurial activity is still at modest levels. Approximately 4\% of them have businesses operating in countries where they live or in Kosovo. Remittances and migration will not lead to sustained economic growth over the medium to long term. Proper public policies, the rule of law are vital to improving the climate for doing business and investing from the outside, laying the foundations for sustainable growth (UNDP, 2014).

Some empirical studies show that remittances can have a positive effect on a country's economic growth. Another set of studies also confirms the great positive impact of remittances on both bank deposit and private sector credit banks. By stimulating investment and consumption, remittances can have the potential to reduce the recession in developing countries as well as boost the local economy. Remittances increase domestic savings and improve financial intermediation, which in return can improve the country of origin perspective. For countries facing transition during the 1990s remittances had a positive effect on aggregate production through investment and entrepreneurial activities. Remittances enable the economy to spend more than it produces, then "Dutch Disease" and greater migration can be encouraged that will increase the dependence on these financing flows (Hoti, 2015).

There are doubts as to whether the Diaspora will continue to contribute the same level of remittances to their families and relatives living in Kosovo in the future. The results of the research suggest that the diaspora's willingness to help Kosovo is not as great as it was in the pre-war period, but remittances will continue even though they will be to a lesser extent. Sustainable income growth for population in the long run cannot be based on remittances alone which are large and resilient to shocks, but unlikely to increase much more. While many Kosovans continue to emigrate and thereby expand their life choices, the high rates of unemployment and enforced economic inactivity demonstrate that emigration is not a solution for everyone. Potential investors include migrants and recipients of remittances who may have funds to invest but currently face numerous uncertainties. Institutions and the private sector should consider how to use the Kosovo Diaspora on one hand for access to international markets, and on the other hand as ambassadors for Kosovo products and exports of services through activities such as international fairs, cultural events and by creation of Associations with Diaspora Businesses. Remittances, will not lead to sustainable economic growth and human development in the medium to long run (UNDP 2014).

Migrants from Kosovo that have businesses in the host countries are more likely to return suggesting the need for policies aiming at improving the business environment and business investment promotion policies to encourage migrants to return and invest utilizing their financial and human capital, and business networks. Such policies should focus on maintaining cooperation among the Kosovo government, Kosovo-based business associations and migrant host-country based business associations in identifying investment opportunities, and the need for customized support in establishing businesses and other relevant government support instruments. 
The Kosovo government is implementing repatriation programmes with host countries. As return migration is more likely among those that have emigrated during the 1998/9 War and lower-income households, it is recommended that the government continues these programmes in the future (Kotorri 2017).

\section{CONCLUSION}

From the data and theories elaborated, it was understood that migration has high tendencies from developing countries to developed ones, where well-being is of a high standard. Also the economic and social standard is extremely high. In Kosovo there have been large movements of the population outside its territory over various periods of time. The reasons have been political and socio-economic. During all periods of migration, the destination of Kosovars has been Western Europe. This movement of people towards western countries will affect the labor market in Kosovo. Some of the jobs such as doctor and engineer will be vacated.

Remittances from the diaspora have had a significant impact on economic growth and on improving the welfare of the Kosovo population. Kosovar diaspora represented a huge and diplomatic network but the institutions dealing with the diaspora lack basic data on demographics and needs of this important diaspora. It can be said that the diaspora has played a key role in the positive changes that have taken place in Kosovo's recent history. The level of diaspora direct investments in Kosovo remains lower than expected. Today, the Kosovar diaspora invests heavily in the real estate sector in Kosovo. Remittances are mainly focused on basic consumption. However, the remittances should be more economically focused especially on development projects.

The Kosovo government needs to improve its business environment. Through business investment promotion policies, the government should encourage migrants to return and invest in Kosovo. Migrants using their financial and human capital will contribute to Kosovo's GDP growth. In conclusion, it can be said that the promotion and creation of investment incentives for the diaspora, especially in partnership with local government, should be the main and important objective of Kosovo institutions that aim at economic and social development of Kosovo. No document or strategy of Kosovo institutions specifies the measures to be taken regarding migration. Therefore, Kosovo institutions need to create special strategies for exploiting the potential of the diaspora in Kosovo's economic development.

\section{REFERENCES}

1. Andersson, FNG. And Karpestam, P. (2018). Economic Perspectives on Migration. Routledge: International Handbook of Migration Studies, 2nd edition, p.1. Available at: https://www.taylorfrancis.com/books/e/9780203863299/chapters/10.4324/9780 203863299-10 [Accessed 20 February 2020]. 
2. Arango, J. (2000). Explaining Migration: A Critical View. International Social Science Journal, 52, (165). https://doi.org/10.1111/1468-2451.00259. Available at: https://onlinelibrary.wiley.com/doi/epdf/10.1111/14682451.00259 [Accessed 18 February 2020].

3. Baković, T., (2010). Managing innovation systems in transition economies. EFZG working paper series, No. 01. Available at: https://hrcak.srce.hr/index.php?show=clanak\&id_clanak_jezik=201921 [Accessed 17 April 2020].

4. Bellaqa, B. and Bajrami, H. (2019). Foreign Direct Investment, Management and Their Role in Economic Development - Kosovo Case. International Journal of Finance \& Banking Studies, 8(3), p.29, DOI: 10.20525/jfbs.v8i3.833. Available at: https://www.ssbfnet.com/ojs/index.php/ijfbs/article/view/484/439 [Accessed 17 February 2020].

5. Bellaqa, B. and Jusufi, G. (2020). Management of Remittances and their role in Economic Development in Kosovo. International Journal of Management Excellence. 14(2), p.2060. DOI: http://dx.doi.org/10.17722/ijme.v14i2. Available at: http://www.ijmeonline.com/index.php/ijme/article/view/645/pdf 183 [Accessed 17 April 2020].

6. Castles, S. (2007). Working papers: Comparing the Experience of Five Major Emigration Countries. University of Oxford: International Migration Institute, Paper 7. Available at: https://ora.ox.ac.uk/objects/uuid:3f4fc3c4-a192-4b1ea833-

41c61714c2a8/download file?file format $=$ pdf\&safe filename $=W P 7 \% 2 B C o m$ paring $\% 2 \mathrm{BFive} \% 2 \mathrm{BC}$ Cuntries.pdf\&type of work=Working + paper $[$ Accessed 16 April 2020].

7. Castelli, F. (2018). Drivers of migration: why do people move?. Journal of Travel Medicine, 25 (1), p.1-7. https://doi.org/10.1093/jtm/tay040. Available at: https://academic.oup.com/jtm/article/25/1/tay040/5056445[Accessed 16 April 2020].

8. CEIC, (2019). Kosovo Remittances 2009-2019. Available at: https://www.ceicdata.com/en/kosovo/balance-of-payments-remittances-bychannel/remittances. [Accessed 20 February 2020].

9. Czaika, M. and Haas, H. (2015). The Globalization of Migration: Has the World Become More Migratory?. International Migration Review, 48(2), p.286. https://doi.org/10.1111/imre.12095. Available at: https://onlinelibrary.wiley.com/doi/full/10.1111/imre.12095 [Accessed 16 April 2020].

10. Dabrowski, M. and Myachenkova, Y. (2018). The Western Balkans on the road to the European Union. Policy Contribution, Issue n 04, p. 2-15. Available at: https://www.bruegel.org/wp-content/uploads/2018/02/PC04 2018.pdf [Accessed 17 February 2020]. 
11. European Commission, (2018). Publication: Why do people migrate? Available at: https://ec.europa.eu/knowledge4policy/publication/why-dopeople-migrate-infographic en [Accessed 20 February 2020].

12. European Stability Initiative, (2015). From Research to policy: Why Kosovo needs migration. Prishtina, p.4. Available at: https://www.esiweb.org/publications/why-kosovo-needs-migration-researchpolicy [Accessed 21 February 2020].

13. Gashi, A. and Haxhikadrija, A. (2012). Kosovo Final Country Report: Social Impact of Emigration and Rural-Urban Migration in Central and Eastern Europe. On behalf of the European Commission DG Employment, Social Affairs and Inclusion \& GVG. p.7, Available at: file:///C:/Users/SoftTech/Downloads/FCR_KOS_main\%20report_EN.pdf [Accessed 11 February 2020].

14. Gashi, Rr. (2018). Remittance Incomes and Economic Development in Kosovo. Prizren Social Science Journal, 2, (2). p.44.

15. Germin \& DANIDA and SDC, (2018). Diaspora Draft Analysis, Prishtina. p.2.

16. GIZ and CIM, (2014). Fourth Regional Workshop on "Migration Policy in the Western Balkans". Focus: Participation of and Cooperation with Migrants, p.5. Available at: http://nasaperspektiva.ba/wp-content/uploads/2015/08/giz2015en-Documentation WS4 Dialogue-with-and-Participation-ofMigrants webversion.pdf [Accessed 13 February 2020].

17. GLPS, (2017). Remittances in Kosovo: Primarily an economic survival tool?, No.03, Prishtina, p.4.

18. Gollopeni, B. (2016). Kosovar Emigration: Causes, Losses and Benefits. Sociologija i prostor, 3 (206), p.195-349.

19. Haug, S. (2008). Migration Networks and Migration Decision-Making. Journal of Ethnic and Migration Studies. 34,(4), https://doi.org/10.1080/13691830801961605. Available at: https://www.tandfonline.com/doi/abs/10.1080/13691830801961605 [Accessed 12 February 2020].

20. Hoti, A. (2015). What Determines the Incidence and Size of Remittances: Evidence for Kosovo. Croatian Economic Survey, 14 (2), p.84, DOI: $10.15179 /$ ces.17.2.3.

21. Jashari, B. and Geci, M. (2018). The Statistical Comparison of Remittances in Kosovo with Balkan Countries. UBT International Conference, Prishtina, (8). p.8, Availabe at: https://knowledgecenter.ubtuni.net $/$ cgi $/$ viewcontent.cgi article $=1948 \&$ context $=$ conference $[$ Accessed 15 February 2020].

22. Jusufi, G. and Lubeniqi, G. (2019). An overview of Doing business in Western Balkan: The analysis of advantages of Doing Business in Kosovo and North Macedonia. Iliria International Review, 9(2), p.168, DOI: 10.21113/iir.v9i2.512.

23. Kosovo Agency of Statistics, (2013). Study on Remittances in Kosovo. Prishtina. 
24. Kosovo Agency of Statistics, (2014). Kosovan Migration, Prishtina. p.21. Availabe at: https://ask.rks-gov.net/media/1380/kosovan-migration-2014.pdf [Accessed 13 February 2020].

25. Kosovo Agency of Statistics KAS, (2019). Estimation: Kosovo Population in 2018, Prishtina. p.8. Availabe at: https://ask.rksgov.net/media/5022/estimation-population-2018.pdf [Accessed 13 February 2020].

26. Kotorri, M. (2010). The Probability of Economic Emigration in Kosovo. Eastern European Economics, 48 (6). https://doi.org/10.2753/EEE00128775480602. Availabe at: https://www.tandfonline.com/doi/abs/10.2753/EEE0012-8775480602 [Accessed 21 February 2020].

27. Kotorri, M. (2017). The Probability of Return Conditional on Migration Duration: Evidence from Kosovo. South East European Journal of Economics and Business, 12 (2), p.43, DOI: 10.1515/jeb-2017-0016. Available at: https://content.sciendo.com/view/journals/jeb/12/2/article-p35.xml [Accessed 22 February 2020].

28. Krasniqi, B.A. and Williams, N. (2019). Migration and intention to return: Entrepreneurial intentions of the diaspora in post-conflict economies. PostCommunist Economies, 31 (1). p.2, DOI: 10.1080/14631377.2018.1505696. Available at: https://www.tandfonline.com/doi/abs/10.1080/14631377.2018.1505696 [Accessed 22 February 2020].

29. Kubursi, A. (2005). The Economics of Migration under Globalization. UNFPA Expert Group Meeting, Marrakech, Morocco. p.160-161 Available at: https://www.unfpa.org/sites/default/files/resourcepdf/migration report 2005.pdf [Accessed 17 April 2020].

30. Kurekova, L. (2011). Theories of migration: Conceptual review and empirical testing in the context of the EU East- West flows. Paper prepared for Interdisciplinary conference on Migration. Economic Change, Social Challenge. April 6-9, 2011, University College London. Available at: https://pdfs.semanticscholar.org/f6cd/407bb33dcee11d834a6dacb2d3ccdb99f9 72.pdff [Accessed 17 April 2020].

31. Martin, P. and Zürcher, G. (2008). Managing Migration: The Global Challenge. Population Bulletin, 63(1), Population Reference Bureau. ISSN 0032-468X, p.6, Available at: http://citeseerx.ist.psu.edu/viewdoc/download?doi=10.1.1.461.587\&rep=rep1\& type $=$ pdf $[$ Accessed 17 April 2020]

32. Morawska, E. (2007). International Migration: Its Various Mechanisms and Different Theories that Try to Explain It. Malmö Institute For Studies of Migration, Diversity and Welfare (MIM) and School of International Migration and Ethnic Relations (IMER), No: 1/07. Available at: http://muep.mau.se/bitstream/handle/2043/5224/WB1\%2007\%20inlaga 1.pdf? sequence $=1 \&$ isAllowed $=y$ [Accessed 17 April 2020]. 
33. Möllers, J., Traikova, D., Herzfeld, Th. and Bajrami, E. (2017). DISCUSSION PAPER: Study on rural migration and return migration in Kosovo. Leibniz Institute of Agricultural Development in Transition Economies, No.166.

34. Mungiu-Pippidi, A. (2005). Seeking the virtuous circle: Migration and Development in the Balkans. Development and Transition, No. 2. p.9. Available at: file:///C:/Users/Soft-Tech/Downloads/SSRN-id1495055.pdf [Accessed 17 February 2020].

35. Mustafa-Topxhiu, R. and Xhelili-Krasniqi, F. (2017). The Relevance of Remittances in Fostering Economic Growth in the West Balkan Countries. Ekonomika, 96 (2). DOI: https://doi.org/10.15388/Ekon.2017.2.10989.

36. Petreski, M., Petreski, B., Tumanoska, D., Narazani, E., Kazazi, F., Ognjanov, G., Jankovic, I., Mustafa, A. and Kochovska, T. (2017). The size and effects of emigration and remittances in the Western-Balkans: Forecasting based on a Delphi process. MPRA Paper No.75512. p.2 Available at: https://mpra.ub.unimuenchen.de/75512/1/MPRA paper 75512.pdf [Accessed 17 February 2020].

37. Pew Research Center, (2018). Remittances from abroad are major economic assets for some developing countries. Available at: https://www.pewresearch.org/fact-tank/2018/01/29/remittances-from-abroadare-major-economic-assets-for-some-developing-countries/ [Accessed 10 February 2020].

38. Prekazi, Y. (2018). Remittance Analysis and their Economic Aspect, Kosovo Case. European Journal of Marketing and Economics, 1(2), p.136. DOI: http://dx.doi.org/10.26417/ejme.v1i2.p135-141.

39. Qorraj. G. and Jusufi, G. (2018). The EU Stabilization and Association Agreement for the Western Balkans: Challenges and Opportunities. Croatian International Relations Review, 23(81), p.51-68. https://doi.org/10.2478/cirr2018-0003.

40. Robinson, T. K. (1977). Economic Policy. Series: Studies in Economics, Palgrave Macmillan, 2nd edition, p.1.

41. Šelo Šabić, S. (2018). Enhanced cooperation to tackle migration - Western Balkans and the Berlin Process. Institute for Development and International Relations (IRMO), p.13.

42. Simpson, N.B. (2017). Demographic and economic determinants of migration: Push and pull factors drive the decision to stay or move, IZA World of Labor, p.373.

43. Sturge, G. (2019). Briefing Paper: Migration Statistics, Number CBP06077, House of Commons Library, UK. p.5.

44. Taylor, J.E. (2006). International Migration and Economic Development. United Nations Secretariat: International Symposium on International Migration and Development, Turin, Italy, 28-30 June 2006, p.2. Available at: https://www.un.org/en/development/desa/population/events/pdf/other/turin/P09 Taylor.pdf [Accessed 17 April 2020].

45. Telli, H. (2014). Less poverty, more emigration: Understanding migrant flows from developing countries. Migration and Development. 3(1). 
https://doi.org/10.1080/21632324.2013.831584. Available at:

https://www.tandfonline.com/doi/abs/10.1080/21632324.2013.831584

[Accessed 17 April 2020].

46. Trading Economics, (2019). Kosovo Unemployment Rate, Available at: https://tradingeconomics.com/kosovo/unemployment-rate [Accessed 17 February 2020].

47. UNDP, (2009). Human Development Reports: Global Economic Prospects for Increasing Developing Country Migration into Developed Countries. Research Paper 2009/50, MPRA Paper No. 19233, p.9.

48. UNDP, (2012). Kosovo Remittance Study 2012, Prishtina. Available at: https://www.undp.org/content/dam/kosovo/docs/Remitances/KRS2012 Englis h 858929.pdf [Accessed 17 February 2020].

49. UNDP, (2014). Kosovo Human Development Report 2014: Migration as a Development Force, Pristina. p.15

50. United Nations Educational, Scientific and Cultural Organization, (2017). Migration and Education, GEM Report, p.7.

51. Vathi, Z. and Black, R. (2007). Migration and Poverty Reduction in Kosovo. The Development Research Centre on Migration, Globalisation and Poverty. University of Sussex, Working paper C12, p.18.

52. Vračić, A. (2019). Policy Brief: Luck like the Irish: How emigration can be good for the Western Balkans. European Council on Foreign Relations, ECFR/277. p, 2-4 Available at: https://www.ecfr.eu/page/luck like the irish how emigration can be good for the western balkans. pdf [Accessed 17 February 2020].

53. WFD., IDN. and Western Balkans Democracy Initiative, (2019). Cost of Youth Emigration. Founded by UK Government. p.23. Available at: https://www.wfd.org/wp-content/uploads/2019/10/WFD-Web-BrochureNM_FINAL.pdf [Accessed 19 February 2020].

54. World Bank, (2011). Migration and Economic Development in Kosovo. Report No. 60590 - XK., p.12.Available at: http://siteresources.worldbank.org/INTKOSOVO/Resources/Migration and E conomic Development in Kosovo_WB report.pdf [Accessed 23 February 2020].

55. Zitnanova, K., (2014). Refugee Protection and International Migration in the Western Balkans. p.5-16, Available at: https://www.unhcr.org/5375c9ab9.pdf [Accessed 19 February 2020]. 


\title{
MIGRACIJE I EKONOMSKI RAZVOJ U ZEMLJAMA ZAPADNOG BALKANA: PRIMJER KOSOVA
}

\author{
Gezim Jusufi \& Mic Ukaj
}

\begin{abstract}
Sažetak
Cilj rada je identificirati utjecaj dijaspore zapadnog Balkana na gospodarski razvoj ovih zemalja, posebno Kosova. Kvalitativnim metodološkim pristupima rad daje pregled $i$ analizu definicije $i$ koncepta migracije, razloga $i$ čimbenika migracija, teorija migracija, glavnih odredišta migranata, specifikacija migracije stanovništva na Kosovo kroz godine, faza migracije stanovništva Kosova, učinaka migracija ili doznaka migranata na gospodarski razvoj Kosova, učinkovitih politika za jačanje veze između dijaspore i razvoja, kanala prijenosa doznaka migranata i tako dalje. Od svih zemalja zapadnog Balkana, Kosovo i dalje pokazuje značajan trend iseljavanja, jer tržište rada ne može apsorbirati velik broj tražitelja posla. Stoga bi kosovske institucije trebale promicati ulaganja i informirati kosovsku dijasporu o mogućnostima poslovanja $i$ reformama koje su provedene na Kosovu. Ograničenja ovog istraživanja mogu biti nedovoljni podaci i statistike o migracijskim trendovima zemalja zapadnog Balkana. Stoga nije bilo moguće ugraditi ekonometrijsku analizu. Vrijednost ovog rada sastoji se u rješavanju migracijskog problema zapadnog Balkana, problema koji je malo riješen u trenutnoj akademskoj literaturi.
\end{abstract}

Ključne riječi: zapadni Balkan, migracije, razvoj, Kosovo, doznake migranata. 